\title{
Instructional Materials for Discovery Learning with Cognitive Conflict Approach to Improve Vocational Students' Achievement
}

\section{Gunawan}

Dr, Universitas Mataram, Indonesia, gunawan@unram.ac.id

\section{Kosim}

Dr, Universitas Mataram, Indonesia, kosim@unram.ac.id

\section{P. Ayu Suci Lestari}

Master Student, Universitas Mataram, Indonesia, p.ayusucilestari@gmail.com

The purpose of this study is to develop an instructional materials using discovery learning with cognitive conflict approach to improve vocational students understanding of heat concept. This instructional material was developed using the Four D model, namely define, design, develop, and disseminate. Furthermore, data were obtained from the syllabus, lesson plans, students' worksheet, learning material and conceptual understanding instruments in the form of multiple-choice question with the product categories validated by three experts. Data were collected by examining the achievement of the learning implementation and questionnaire responses of teachers and students that obtained very high practicality categories. Therefore, the instructional materials developed can be stated that feasible and practical to implement with a positive impact on students' conceptual understanding.

Keywords: instructional materials, discovery learning, cognitive conflict, heat concept, learning, vocational students

\section{INTRODUCTION}

The new paradigm in learning physics requires the design of innovative instructional material. Research on the development of the innovative instructional materials is a study that enhances the quality of existing learning tools in order to positively improve vocational high school students. These students come from a variety of different junior high schools to obtain diverse initial conceptions, such as the heat theory in physics.

Based on the preliminary study conducted at one of the vocational high schools in Mataram, it was found that students are generally interested in learning physics. However, innovative instructional materials to facilitate students understanding concepts

Citation: Gunawan, Kosim, \& Lestari, P. A. S. (2020). Instructional Materials for Discovery Learning with Cognitive Conflict Approach to Improve Vocational Students' Achievement. International Journal of Instruction, 13(3), 433-444. https://doi.org/10.29333/iji.2020.13330a 
are yet to be produced, thereby, leading to poor outcomes as seen in the minimum completeness which are still below average. Other researchers also included that at the vocational high school level there is often a failure in maximizing the quality of graduates due to lack of motivation and enthusiasm (Yang, 2015), use of outdated learning models (Kusumaningrum et al., 2016), and inability to implement the right learning materials (Emir, 2013).

This shows that student's physics learning outcomes are related to the inability to connect the ideas obtained at the junior high school level. In addition, the utilization of poor instructional materials, are less able to facilitate students understanding especially in the field of heat material (Baser, 2006).

Various innovations can be carried out to ameliorate the inconsistencies associated with this course one of which is by developing practical instructional materials, able to support practical activities and provide a flexible platform for students to express their ideas. Research about development of instructional materials for discovery learning model with cognitive conflict approach has been much carried out by other researchers (Baser, 2006; Tompo et al., 2016). So far, only instructional materials with discovery models or with cognitive conflict approaches alone have been developed (Madu \& Orji, 2015; Yuliani \& Saragih, 2015). This new discovery learning model combines both techniques. However, the shortcomings of the discovery learning model can be complemented by the advantages possessed by the cognitive conflict approach which encourages students to be more active in expressing ideas while evaluating their knowledge (Madu \& Orji, 2015).

According to previous research, the development of instructional materials using discovery models improves students' understanding concepts (Rahmadani et al., 2017; Yusuf \& Wulan, 2016), hone skills (In'am \& Hajar, 2017), and improve problem solving abilities (Fuad et al., 2017). Acquiring knowledge with discovery learning model also influences the critical thinking abilities of students. Good learning requires students to use various learning resources in order to find (discover) concepts that are in a material (Gunawan et al., 2019).

The cognitive conflict approach was also summarized effective for enhancing understanding (Baser, 2006; Basir \& Karmila, 2015), and high-level abilities (Suryadi et al., 2015). Its learning tools have also stated to have good validity and practicality level (Alabi et al., 2015). In addition, it slowly addresses and equates students' concept on the subject (Bose, 2015; Huang, 2008).

The purpose of this research is to develop instructional materials for discovery model with cognitive conflict approach consisting of the syllabus, lesson plans, student worksheet, and learning material. Furthermore, the study aims at testing these instructional materials to determine the practicality of the academic process based on the teachers and students responses, in accordance with understanding heat material concept. 


\section{CONTEXT AND REVIEW OF LITERATURE}

Development research is used to create better quality instructional materials using models and cognitive conflict approaches. However, the discovery model is a set of learning activities that encourages students to actively determine perception through observation. According to Shah (2004), there are several procedures that must be implemented in teaching and learning activities in order to apply this method such as stimulation, problem statement, data collection, data processing, verification, and generalization.

Cognitive conflict is a set of learning activities that aim to turn students' misconceptions into scientific conceptions (Madu \& Orji, 2015; Yuruk \& Eroglu, 2016). According to Suparno (2005), these steps include: expressing students' initial notion explicitly, discussing and evaluate initial concepts, creating conceptual conflict against the original idea, and encouraging and directing students to restructure their theory. The learning steps obtained as a result of combining the model discovery and cognitive approaches are shown in Table 1 below.

Table 1

Steps of Discovery Learning Model with the Cognitive Conflict Approach

\begin{tabular}{|c|c|c|}
\hline No. & $\begin{array}{l}\text { Steps of the Discovery } \\
\text { Learning Model }\end{array}$ & Steps of the Cognitive Conflict Approach \\
\hline \multirow{2}{*}{1} & \multirow{2}{*}{ Stimulation } & Reveal the initial concepts of students \\
\hline & & Discussing and evaluating the initial concepts \\
\hline 2 & Problem Statement & $\begin{array}{l}\text { Creating conceptual conflicts against the initial } \\
\text { concept }\end{array}$ \\
\hline 3 & Data Collection & \multirow{4}{*}{$\begin{array}{l}\text { Energizing and directing students to restructure } \\
\text { their concepts }\end{array}$} \\
\hline 4 & Data Processing & \\
\hline 5 & Verification & \\
\hline 6 & Generalization & \\
\hline
\end{tabular}

The application of an appropriate learning model must also be accompanied by a good understanding of students' conceptual understanding. Understanding the the concept is an understanding of abstraction or description of ideas that represent several objects, events, activities, or relationships with the same characteristics (Bilgin, et al., 2017). In Bloom's cognitive domain taxonomy in Prasetyarini (2013), conceptual understanding is divided into three aspects, namely translation (translating ability), in the form of the ability to change certain symbols without changing meanings, interpretation (ability to interpret), in the form of the ability to explain the meaning contained in a symbol (verbal and nonverbal), and extrapolation (ability to predict).

On the hot concept, there are still many difficulties found in achieving good students' understanding. In Alwan's (2011) it was found that many students had diverse notion of the heat material with difficulties in making connections between knowledge and everyday experience (Gonen et al., 2010), as well as between current learning and those previously gained (Daud et al., 2015), for proper interpretation and understanding. Thus learning capable of reducing the gap that occurs in students especially in heat material is required. Learning that requires students to actively find and build their own knowledge, 
has been proven to increase student learning achievement (Wahyuni et al., 2019). Therefore, discovery-based learning that is supported by an appropriate approach and good instructional materials will greatly help students improve their learning achievement.

The description that the author has provided gives an insight into the importance of good instructional material. Based on this, we have provided a good solution to the problem of lack of student achievement. The solution is to develop instructional material for discovery learning with cognitive conflict approach. Its development requires a long process and provides good data to provide a more detailed understanding of student learning achievement.

\section{METHOD}

This research is a study that develops instructional materials using a discovery model with cognitive conflict approach on heat material. The products developed in this study consisted of the syllabus, lesson plans, students' worksheet, learning materials, and conceptual understanding instruments in the form of multiple choice questions. It adopted the instructional materials consisting by Four D Model (Thiagarajan et al., 1974) which comprises of define, design, develop, and disseminate stages.

\section{Define}

At this stage, a preliminary analysis consisting of literature and field studies was conducted by collecting various references to obtain information related to the instructional materials and its application.

\section{Design}

At this stage, answers are provided in line to the needs of the school in accordance to the learning tool and its application by selecting the instructional materials format to be developed and test standard to be utilized. The design made by researchers was of instructional materials by discovery model combined with cognitive conflict approaches.

\section{Develop}

At this stage, instructional materials were developed by discovery model with cognitive conflict approaches in order to enhance students' understanding of physics concept. It was also carry out to measure and analyze the level of achievement of learning implementation, teacher and student response, and learners understanding.

\section{Disseminate}

After implementing define, design, and develop stages, the disseminate phase was then carried out to publicize the results.

Instructional materials were applied in one of the Vocational Schools in Mataram. The application of this learning was practically carried out by a model teacher for three meetings in a class containing a total of 25 students. Data were collected through observation and teacher/student response to questionnaires. The results in the 
observation and questionnaire sheets were then analyzed in percentage using the following formula.

$$
\text { Practical Percentage }=\frac{\text { Total score }}{\text { Max Score }} \times 100 \%
$$

Based on the percentage of practicality level obtained, the practicality criterion of the learning process is determined according to Table 2 below.

Table 2

Categories for Practicality

\begin{tabular}{ll}
\hline Practicality Range (\%) & Practicality Level \\
\hline $0-20$ & Very low \\
$21-40$ & Low \\
$41-60$ & Sufficient \\
$61-80$ & Height \\
$81-100$ & Very High \\
\hline
\end{tabular}

(Source: Arikunto, 2013)

\section{FINDINGS}

Development of instructional materials using discovery model and cognitive conflict approaches have been validated by three expert lecturers. The researcher has also revised the product developed in accordance with the advice given by the expatriates. After revising the product, a test of the question instrument is carried out to obtain data on the level of validity, reliability, power difference, and difficulty of each item. Furthermore, a test was conducted to validate the obtained data using product moment correlation formula, Sperman Brown formula, different power test, and difficulty level use different power formula and discrimination index.

This study applies discovery model learning tools with conflict approaches that have been revised to obtain data on the practicality level of the learning process. Data was obtained from learning performance achievement by observers, teacher and learners responses to educational process, and student final grade data related to the level of understanding of their concepts. The results of the analysis of the achievement can be shown in Figure 1 below.

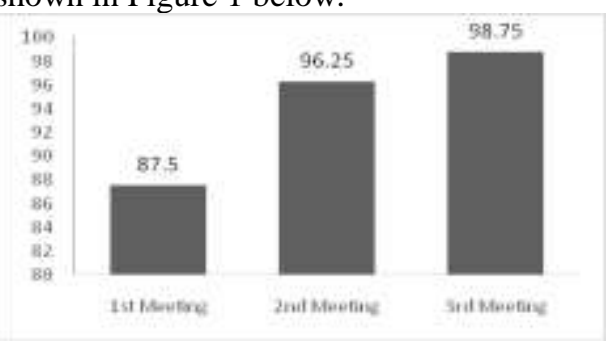

Figure 1

Percentage of Achievement of Learning Implementation

Based on the learning feasibility percentage in Figure 1, it can be seen that the first to 
the third meeting was implemented in the range of $81 \%-100 \%$ which is in the very high categories.

The researcher also analyzed the data based on the results of the teacher's response and students' responses to the application of the developed tools. The result of the analysis is shown in Table 3 below.

Table 3

Percentage of Teacher Response and Students' Response

\begin{tabular}{lllll}
\hline & $\begin{array}{l}\text { Learning } \\
\text { Process } \\
(\%)\end{array}$ & $\begin{array}{l}\text { Learning } \\
\text { Materials } \\
(\%)\end{array}$ & $\begin{array}{l}\text { Students } \\
\text { Worksheet } \\
(\%)\end{array}$ & $\begin{array}{l}\text { Understanding the } \\
\text { Concept Instrument } \\
(\%)\end{array}$ \\
\hline Teacher Response & 91.67 & 100.00 & 93.33 & 90.00 \\
\hline Students' Response & 79.04 & 77.28 & 79.47 & 75.04 \\
\hline Average & 85.36 & 88.64 & 86.40 & 82.52 \\
\hline
\end{tabular}

Table 3 shows that the average teacher and student responses in all aspects are in the range between $81 \%-100 \%$, and if based on Table 2, it is included in the very high practicality categories.

After the learning process was complete, the researcher also measures the level of understanding of students' concepts by giving them the opportunity to answer twentyfive multiple choice questions. Their final scores can be shown in Table 4 below.

Table 4

Students' Achievement

\begin{tabular}{lllll}
\hline No. & Class & Number of Students & Average & Standard Deviation \\
\hline 1 & X Bs2 & 25 & 89.44 & 9.37 \\
\hline
\end{tabular}

Based on Table 4, it appears that the average value of class X Bs2 students is 89.44 with a standard deviation of 9.37 . This shows that the learning tools applied have a positive impact on the level of understanding of students' ideas.

Table 5

Students' Achievement Based on Sub Material

\begin{tabular}{llllll}
\hline & \multicolumn{2}{l}{ Students Achievement } & & \\
\cline { 2 - 6 } & Sub & Sub & Sub & Sub & Sub \\
& Materials & Materials & Materials & Materials & Materials \\
& I & II & III & IV & V \\
\hline Total Score of Students' & 113 & 111 & 112 & 108 & 115 \\
\hline Max Score & 125 & 125 & 125 & 125 & 125 \\
\hline The Percentage (\%) & 90.40 & 88.80 & 89.60 & 86.40 & 92.00 \\
\hline
\end{tabular}

Table 5, classifies student grades based on each heat sub material temperature, expansion, heat, Black principle, and heat transfer with its percentage range between $81 \%-100 \%$. The value of students' conceptual comprehension based on Table 2, is classified as very high categories.

In addition to classifying the final grades of students based on sub-material, researchers also classify students' final grades in accordance with the cognitive levels shown in 
Table 6 below.

Table 6

Students' Achievement Based on Cognitive Level

\begin{tabular}{lllllll}
\hline & \multicolumn{2}{l}{ Students' Achievement } & & & \\
\cline { 2 - 8 } & C1 & C2 & C3 & C5 & C6 \\
& $(4,11$, & $(15,22$, & $(1,2,6,12,13$, & $(3,5,8,18$ & $(7,10$, & $(9$, \\
& $16)$ & $23,25)$ & $17,19,21)$ & $, 20)$ & $14)$ & $24)$ \\
\hline Total Score of Students' & 66 & 91 & 179 & 112 & 65 & 46 \\
\hline Max Score & 75 & 100 & 200 & 125 & 75 & 50 \\
\hline The Persentage (\%) & 88,00 & 91.00 & 89.60 & 89.60 & 86.67 & 92.00 \\
\hline
\end{tabular}

Table 6 shows the students' achievement of conceptual understanding classified per cognitive level consisting of $\mathrm{C} 1, \mathrm{C} 2, \mathrm{C} 3, \mathrm{C} 4, \mathrm{C} 5$, and C6. All gains range between $81 \%$ $100 \%$ with very high categories when based on Table 2 .

\section{DISCUSSION}

Instructional materials using discovery model with cognitive conflict approach developed by the researcher had been validated. The results show a very high efficacy level of all components because each component developed was between $81 \%-100 \%$. These results are reinforced by the statement of previous researchers that the validity level of instructional materials developed by discovery models is high (Rambe et al., 2018; Yuliani \& Saragih, 2015) and good validity levels (Tompo et al., 2017).

During the validation process, there were suggestions given by improve the product being developed using the learning activities presented in the syllabus table. Based on the suggestions, the researcher revised by clarifying the steps involved in the syllabus according to the syntax of discovery using cognitive conflict approaches.

The next resolution is to enhance the developed lesson plan used in allocating time which was previously grouped based on preliminary, core and closing activities with revisions made based on each syntax. In addition, suggestions were made for operationalizing the learning steps to be more specific at the first, second, and third meeting which the researcher redesigned to be more operational and in accordance with the scenario or concrete steps taken during the learning process.

Suggestions for students' worksheet had been developed by researchers to improve the layout and systematic writing editor. Therefore, it was more operational and easier to understand. Learning material developed by researchers also received suggestions for improvement from expert validators revisions are made by completing each picture by including a reference to its sources.

The revision was also carried out on test instruments for understanding concepts developed by researchers. Suggestions from the validator were to simplify a few sentences on the same meaningful questions. In addition, a re-adjustment of the cognitive categories was also carried out on each question starting from $\mathrm{C} 1$ to $\mathrm{C} 6$ with the original answer choices $(\mathrm{a}, \mathrm{b}, \mathrm{c}, \mathrm{d}, \mathrm{e})$ changed to those of the validator $(\mathrm{A}, \mathrm{B}, \mathrm{C}, \mathrm{D}$, E). In addition, the answer which was initially written vertically became horizontal and 
quite short.

After the product has been revised, the test instruments are conducted so that the learning tools applied to one of the Vocational Schools in Mataram are in line with the syllabus of the meeting.

The implementation of learning in the first meeting was $87.50 \%$ which was lower than the second and third meeting which were $96.25 \%$ and $98.75 \%$ respectively. This is because the teachers of the model are increasingly accustomed to applying learning tools developed by researchers, thereby minimizing the various shortfalls inherent the system. The results obtained are in line with research from Prasetyana et al. (2015) who found that implementing a discovery model device was in the high category. Besides that Hartini et al. (2018) also found its model to be $89 \%$ practical. Similarly, Indiastuti (2016), study namely showed the instructional materials utilized to be practical.

In addition to analyzing the level of achievement in accordance with learning, the teachers and students responses to questionnaires related to product development applied in the classroom were examined. The results of student responses to the learning process, material, worksheet, and conceptual understanding instruments were between $75 \%-80 \%$, which is quite good although not as high as the teacher's response percentage of above $90 \%$. This was obtained because some learners were still relatively new to the model.

Based on the results analysis of the teacher and student responses to the learning process, the average percentage is between $81 \%-100 \%$ which is classified very high. The results obtained are in line with those obtained Allo et al. (2015) who argued that physics instructional materials had met the practical categories, thereby making it suitable for use in the classroom. Other researchers also stated that students gave a positive response to the knowledge acquisition techniques (Leung et al., 2018), with the response of teachers and students to the products in the very feasible a practical category (Wulandari et al., 2018). This makes learning more practical when applying the discovery models (Alabi et al., 2015).

When measuring the concept's level of understanding using 25 multiple choice questions, students also obtained a high final score from each sub-material and cognitive level. The highest heat transfer was $92.00 \%$, while the lowest amounted to $86.40 \%$. However, the difference in acquisition is included in the high categories because it is between $81 \%-100 \%$.

The results of this study are reinforced by Dedonno (2016); Kunsting et al. (2013); and Kistner et al. (2016) which stated that the application of learning dominated by the discovery process would further enhance students' understanding of concepts. Other researchers also stated that instructional materials affect increasing significant understanding concept (Gunawan et al., 2018). Another study found that the implementation of cognitive conflict approaches in effective knowledge acquisition aids to enhance understanding of ideas (Baser, 2006; Basir \& Karmila, 2015), and places students in high categories (Suryadi et al., 2015). 


\section{CONCLUSION}

Based on the results and analysis conducted, it was found that the instructional materials using a discovery model with cognitive conflict approach developed a very high level of validity and practicality. In addition, it also has a positive impact on students' conceptual understanding, especially in heat material. Therefore, it can be concluded that this model is very feasible and practical to be applied in the classroom.

\section{REFERENCES}

Alabi, T. O., \& Lasisi, N. (2015). Effect of discovery and problem solving on achievement of secondary school students in volumetric analysis in Niger State. Journal of Science, Technology, \& Education, 3(4), 75-87.

Allo, A. Y., Jatmiko, B., \& Agustini, R. (2015). Pengembangan Perangkat Pembelajaran Fisika Model Guided Discovery Learning Menggunakan Alat Sederhana untuk Mereduksi Miskonsepsi Siswa SMA pada Materi Fluida Statis. Jurnal Pendidikan Sains Pascasarjana Universitas Negeri Surabaya, 5(1), 769-778.

Alwan, A. A. (2011). Misconception of heat and temperature among physics students. Procedia Social and Behavioral Sciences, 12, 600-614.

Arikunto, Suharsimi. (2013). Prosedur penelitian. Jakarta: Bumi Aksara.

Baser, M. (2006). fostering conceptual change by cognitive conflict based instruction on students understanding of heat and temperature concept. Eurasia Journal of Mathematics, Science and Technology Education, 2(2), 96-114

Basir, F., \& Karmila. (2015). Keefektifan Strategi Konflik Kognitif Terhadap Pemahaman Konsep Matematika Siswa. Prosiding Seminar Nasional, 2(1), 514-521.

Bilgin, A. K., Yurukel, F. N. D., \& Yigit, N. (2017). the effect of a developed REACT strategy on the conceptual understanding of students: "Particulate nature of matter". Journal of Turkish Science Education, 14(2), 65-81.

Bose, U. (2015). Design and evaluating of a group support system supported process to resolve cognitive conflict. Computers in Human Behavior, 49, 303-312.

Daud, N. S. N., Karim, M. M. A., Hassan, S. W. N. W., \& Rahman, N. A. (2015). Misconception and difficulties in introductory physics among high school and university students: An overview in mechanics. EDUCATUM-Journal of Science, Mathematics, and Technology, 2(1), 34-47.

Dedonno, M. A. (2016). The influence of IQ on pure discovery and guided discovery learning of a complex real-world task. Learning and Individual Differences, 49, 11-16.

Emir, O. (2013). The effect of training on vocational high school students in their professional development. Procedia-Social and Behavioral Science, 106, 2274-2738.

Fuad, N. M., Zubaidah, S., Mahanal, S., Suriasni, \& Endang. (2017). Improving junior high schools critical thinking skills based on test different models of learning. 
International Journal of Instruction, 10(1), 101-116.

Gonen, S., \& Kocakarya, S. (2010). A cross-age study on the understanding of heat and temperature. Eurasian Journal of Physics and Chemistry Education, 2(1), 1-15.

Gunawan, G., Harjono, A., Hermansyah, H., \& Herayanti, L. (2019). Guided inquiry model through virtual laboratory to enhance students'science process skills on heat concept. Jurnal Cakrawala Pendidikan, 38(2), 259-268.

Gunawan, G., Nisrina, N., Suranti, N. M. Y., Herayanti, L., \& Rahmatiah, R. (2018). Virtual laboratory to improve students' conceptual understanding in physics learning. Journal of Physics: Conference Series, 1108(1), 012049.

Hartini, L., Zainuddin., \& Miriam, S. (2018). Pengembangan Perangkat Pembelajaran Beorientasi Keterampilan Proses Sains Menggunakan Model Inquiry Discovery Learning Terbimbing. Berkala Ilmiah Pendidikan Fisika, 6(1), 69-82.

Huang, T., Liu, Y., \& Shiu, C. (2008). Construction of an online learning system for decimal numbers through the use of cognitive conflict strategy. Computed and Education, 50, 61-6.

In'am, A., \& Hajar, S. (2017). Learning geometry through discovery learning using a scientific approach. International Journal of Instruction, 10(1), 55-70.

Indiastuti, F. (2016). Pengembangan Perangkat Model Discovery Learning Berpendekatan Saintifik untuk Meningkatkan Berpikir Kreatif dan rasa Ingin Tahu. Jurnal Pendidikan Matematika RAFA, 2(1), 41-55.

Kistner, S., Vollmeyer, R., Burns, B. D., \& Kortenkamp, U. (2016). Model development in scientific discovery learning with a computer-based physics task. Computers in Human Behavior, 59, 446-455.

Kunsting, J., Kempf, J., \& Wirth, J. (2013). Enhancing scientific discovery learning through metacognitive support. Contemporary Educational Psychology, 38, 349-360.

Kusumaningrum, Indrati., Hidayat, Hendra., Ganefri., Anori, Sartika., and Dewy, Mega Silfia. (2016). Learning outcomes in vocational education: A business plan development by production-based learning model approach. International Journal of Environmental and Science Education, 11(18), 11917-11930.

Leung, A. W., Hasratuddin., \& Syahputra, H. (2018). Development of learning devices based on discovery learning assisted geogebra models to improve self-regulated learning of students at SMP Negeri 1 Stabat. American Journal of Educational Research, 6(12), 1646-1653.

Madu, B. C., \& Orji, E. (2015). Effect of cognitive conflict instructional strategy on students conceptual change in temperature and heat. Sage Open, 5(3), 1-9. https://doi.org/10.1177/2158244015594662.

Makhrus, M., Nur, M., \& Widodo, W. (2014). Model Perubahan Konseptual dengan Pendekatan Konflik Kognitif (MPK-PKK). Jurnal Pijar MIPA, 9(1), 20-25. 
Nuryakin \& Riandi. (2017). Improving middle school students' critical thinking skills through reading infusion-loaded discovery learning model in the science instruction. Journal of Physics: Conference Series, 812, 1-6.

Prasetyana, S. D., Sajidan., \& dan Maridi. (2015). Pengembangan Model Pembelajaran Discovery Learning yang Diintegrasikan dengan Group Investigation pada Materi Protista Kelas X SMA Negeri Karangpandan. Jurnal Inkuiri, 4(2), 135-148

Prasetyarini, A., Fatmaryani, S. D., \& Akhdinirwanto, R. W. (2013). Pemanfaatan Alat Peraga IPA untuk Peningkatan Pemahaman Konsep Fisika pada Siswa SMP Negeri 1 Buluspensantren Kebumen Tahun Pelajaran 2012/2013. Jurnal Radiasi, 2(1), 7-10.

Prihantini, G. S. (2016). Strategi Belajar. Malang: UMM Press.

Rahmadani, E., Fauzi, M. A., \& Karnasih, I. (2017). Pengembangan Perangkat Pembelajaran Berbasis Model Discovery Learning Untuk Meningkatkan Kemampuan Pemahaman Konsep Dan Diposisi Matematis Siswa Berbantuan Geoboard. Jurnal Paradikma, 10(2), 106-117.

Rambe, J. A., Sinaga, B., \& Yusnadi. (2018). The development of learning devices based on discovery learning to improve mathematical creative thinking ability of student class v at SD Negeri 060827 Medan Amplas. Journal of Education and Practice, 9(9), 72-79.

Suparno, P. (2015). Miskonsepsi dan Perubahan Konsep dalam Pendidikan Fisika. Jakarta: PT Grasindo.

Suryadi, A., Ali, M. S., \& Rusli, M. A. (2015). Peranan Strategi Pembelajaran Konflik Kognitif Terhadap Pemahaman Konsep Fisika Peserta Didik Madrasah Aliyah Negeri Pangkep. Jurnal Sains dan Pendidikan Fisika, 11(2), 141-149.

Syah, M. 2004. Psikologi Pendidikan dengan Pendekatan Baru. Bandung: PT Remaja Rosdakarya.

Thiagarajan, S., Semmel, D. S., \& Semmel, M. I. (1974). Instructional development for training teachers of exceptional children. Minneapolis, Minnesota: Leadership Training Institute/Special Education, University of Minnesota.

Tompo, B., Ahmad, A., \& Muris, M. (2016). The development of discovery-inquiry learning model to reduce the science misconception of junior high school students. International Journal of Environmental and Science Education, 11(12), 5676-5686.

Wahyuni, S., Kosim, Gunawan, \& Husein, S. (2019). Physics learning devices based on guided inquiry with experiment to improve students' creativity. Journal of Physics: Conference Series, 1233(1), p. 012034.

Wulandari, D., Rosiana, A., \& Abidin, H. A. Z. (2018). The development of science teaching materials based on practicum in applying motion energy concept topic. Advance in Social Science, Education, and Humanities Research, 303, 189-194.

Yang, Ya-Ting Carolyn. (2015). Virtual CEOs: A blended approach to digital gaming 
for enhancing higher order thinking and academic achievement among vocational high school students. Computer and Education, 81, 281-295.

Yuliani, K., \& Saragih, S. (2015). The development of learning based guided discovery model to improve understanding concept and critical thinking mathematical ability of students at Islamic junior high school of medan. Journal of Education and Practice, 6(24), 116-128.

Yuruk, N., \& Eroglu, P. (2016). the effect of conceptual change texts enriched with metaconceptual processes on preservice science teachers' conceptual understanding of heat and temperature. Journal of Baltic Science Education, 15(6), 693-705.

Yusuf, M., \& Wulan, A. R. (2016). Penerapan Model Discovery Learning Tipe Shared dan Webbed untuk Meningkatkan Penguasaan Konsep dan KPS Siswa. Jurnal Edusains, 8(1), 48-56. 